\title{
Prepartum lameness on subsequent lactation in Holstein dairy cows
}

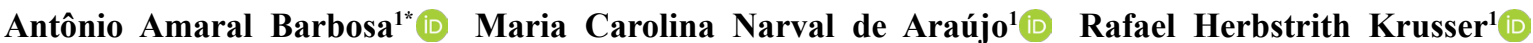 Charles Ferreira Martins ${ }^{2}$ (D) Eduardo Schmitt ${ }^{2}$ (iD) Viviane Rohrig Rabassa ${ }^{2}$ (iD) Francisco Augusto Burkert Del Pino ${ }^{3}$ iD Cássio Cassal Brauner ${ }^{4}$ iD Marcio Nunes Corrêa $^{2}$ (D)}

${ }^{1}$ Programa de Pós-graduação em Veterinária, Universidade Federal de Pelotas (UFPel), 96160-000, Pelotas, RS, Brasil. E-mail: antoniobarbosa.vet@hotmail.com. "Corresponding author.

${ }^{2}$ Departamento de Clínicas Veterinária, Faculdade de Veterinária, Universidade Federal de Pelotas (UFPel), Pelotas, RS, Brasil.

${ }^{3}$ Centro de Ciências Químicas, Farmacêuticas e de Alimentos, Faculdade de Bioquímica e Bioprospecção, Universidade Federal de Pelotas (UFPel), Pelotas, RS, Brasil.

${ }^{4}$ Departamento de Zootecnia, Faculdade de Agronomia Eliseu Maciel, Universidade Federal de Pelotas (UFPel), Pelotas, RS, Brasil.

ABSTRACT: The aim of this study was to confirm the possible consequences of prepartum lameness on subsequent lactation among Holstein cows. In this research, 27 multiparous cows, were monitored from the $30^{\text {th }}$ to $63^{\text {rd }}$ day, relative to calving. Thirty days prior to parturition, the animals were segregated into two groups based on the locomotion score (LS), where LS 1 is attributed to animals without claudication, LS 2 to those with suspected lameness and LS 3, 4 and 5 to those with mild, moderate and severe lameness, respectively; in the lame cows group (LC) $(n=15)$, the animals displayed $L S \geq 3$, whereas in the non-lame cows group $(N L C)(n=12)$ they showed LS 1. Milk production, body condition score (BCS) and blood concentration levels of $\beta$-hydroxybutyrate (BHB), urea, phosphorus, calcium aspartate aminotransferase (AST), gamma glutamyl transferase (GGT) and total plasma proteins (PPT) were evaluated. Milk production (17.675 \pm 0.31 L of milk/day) and blood calcium concentration $(7.42 \pm 0.12 \mathrm{mg} / \mathrm{dL}$ ) were lower in the lame cows in comparison to those without lameness (22.27 $\pm 0.42 \mathrm{~L}$ of milk/day and $9.63 \pm 0.13 \mathrm{mg} / \mathrm{dL}$ ). Besides, the lame cows showed higher BCS loss during the early postpartum period. The metabolites AST, GGT, PPT, urea, BHB and phosphorus revealed no difference between the groups during the period evaluated. The lameness evident in cows during prepartum exerted major negative effects on the milk production and calcemia, making the LS evaluation during these period an important tool in the early diagnosis of losses for future lactation.

Key words: lameness, cow, transition period.

Impactos da claudicação pré-parto na lactação subsequente de vacas leiteiras da raça Holandês

RESUMO: O objetivo deste estudo foi verificar as consequências da claudicação no periodo pré-parto no início da lactação subsequente de vacas da raça Holandês. Vinte e sete vacas multíparas foram monitoradas do dia -30 até o dia 63 em relação ao parto. Trinta dias antes do parto os animais foram divididos em dois grupos de acordo com classificação de escore de locomoção (EL) em que EL é atribuído ao animal sem claudicação, EL 2 suspeito de claudicar e EL 3, 4 e 5 representam claudicação leve, moderada e severa, respectivamente. No grupo de vacas claudicantes $(n=15)$ os animais apresentavam EL $\geq 3$ e no grupo controle $(n=12)$ apresentavam EL de 1 . Foi mensurada a produção de leite, escore de condição corporal (ECC) e as concentrações sanguíneas de B-hidroxibutirato (BHB), ureia, fósforo, cálcio, aspartato aminotransferase (AST), gama glutamil transferase (GGT) e proteinas plastmáticas totais (PPT). A produção média de leite das vacas claudicantes $(17,675 \pm 0,31 \mathrm{~L} /$ dia) e concentração de cálcio sanguíneo (7,42 \pm 0,12 mg/dL) foram menores quando comparadas com as nãoclaudicantes $(22,27 \pm 0,42 \mathrm{~L} /$ dia e 9,63 17,675 $\pm 0,13 \mathrm{mg} / \mathrm{dL})$. Além disso, vacas claudicantes perderam mais ECC no pós-parto recente. Os metabólitos AST, GGT, PPT, ureia, BHB e fósforo não diferiram entre grupos durante o periodo avaliado. A claudicação evidente em vacas no pré-parto apresenta grandes reflexos negativos na produção de leite e calcemia desses animais, tornando o EL pré-parto uma ferramenta importante no diagnóstico precoce de prejuízos na futura lactação.

Palavras-chave: claudicação, vacas, período de transição.

\section{INTRODUCTION}

Lameness is considered the major cause of pain and discomfort, especially in dairy cattle, culminating in direct impacts on their welfare, precipitating considerable economic losses, and indicating a significant problem in terms of the damages it causes to the productive system (SOUZA et al., 2006). Although, lameness ranks third in the order of disease prevalence, second only to mastitis and reproductive diseases, it is the biggest reason for economic losses in dairy cows (GREENOUGH, 
2007), because they are the main cause for the losses. The economic losses induced by foot lameness occur due to the premature disposal of the animals (usually the most productive), decreased milk production, treatment costs, longer service rate and diminished rate of fertility and mastitis on the properties (CHA et al., 2010; BARBOSA et al., 2018). Despite the significance of this problem, the lack of studies hinders the correct understanding of the magnitude of the problem and its associated factors, in the Brazilian context (TOMASELLA et al., 2014; COSTA et al., 2018).

In this context, the means used to assess and quantify the impacts on the productive system assume even greater importance (SOUZA et al., 2006; GREENOUGH, 2007). Besides, changes in health, such as weight loss, prolonged anestrus, decreased milk production and nutritional deficiencies have been reported in cows with foot injuries, particularly severe lameness, thus demonstrating the multiple negative results that these diseases can produce (GARBARINO et al., 2004). Dairy farmers often underestimate the influence lameness can exert on their herds (GREEN, 2014; ESPEJO; WHAY, 2014; ŠÁROVÁ et al., 2011). Thus, the fact of not being aware of the lameness in their cattle makes them tolerate one more important issue or veil a reality that they are experience in their systems, thus limiting the control and prevention initiatives they could employ. The prevalence of lameness may be decreased when the producers become conscious of the real problem in their properties (LEACH et al., 2013). The availability of reports on the prevalence of lameness in the herd (CHAPINAL et al., 2014) may facilitate a reduction in the occurrence of foot disorders in the properties, thus facilitating the execution of locomotion score (LS) and body condition score (BCS), key factors in control. Benchmarking is another tool that permits a relative performance assessment, which analyzes the results based on the comparative position, relative to the others (BICALHO et al., 2009; MORIARTY, 2011; BOGETOFT, 2012; BARBOSA et al., 2016).

Subjective observational assessment methods such as the LS and BCS, for example, have been widely used in population assessments of the different degrees of lameness and nutritional status of the animals. These methods are easy to apply and facilitate monitoring without any cost involved (BARBOSA et al., 2016). However, running this tool during the dry or non-lactating period has been applied rather rarely, often because of the lack of attention being paid to the care of the animals at this time.

The dry period usually extends for about 60 days and is a lactation resting time for the dairy cow during the production cycle, as well as a phase during which important changes occur. It is very important to reduce and minimize the impacts that such changes may exert on the metabolism of the animal, providing adequate transition at the commencement of lactation (DRACKLEY, 1999). However, most producers have ignored the dry period, under the misconception that as the animals are not producing milk at this time they will not require attention and monitoring.

The BCS and LS are subjective and visual evaluations that have a direct and inversely proportional relationship (BICALHO et al., 2009; BARBOSA et al., 2018) demonstrating a relationship between the BCS, digital cushion thickness and LS. Thus, the higher the BCS value, the thicker the digital cushion composed of an adipose tissue layer; and therefore, a high absorption of the digital impact on the floor, lowering the chance of lameness.

Studies are available that reveal the negative impacts of lameness on metabolism (BARBOSA, 2018) and even estimates the loss of milk yield based on different locomotion scores in dairy cows; however, only little research has been done related to the effects of prepartum lameness on postpartum lactation. Thus, the objective of this study was to verify the most likely results of prepartum lameness on subsequent lactation in terms of energy, mineral and biochemical metabolism and milk production in Holstein cows.

\section{MATERIALS AND METHODS}

Among a herd of 193 multiparous Holstein cows, 27 healthy cows were studied, barring the group with the lame animals, which possessed lesions in the locomotor system. Animals which exhibited any health issue with the mammary glands and / or reproductive system during the entire experimental period were excluded from the study. The entire experimental population was given the same diet, and installed in a commercial farm in the south part of southern Brazil, in the city of Capão do Leão/ Rio Grande do Sul, which had 1,180 animals and a total of 721 lactating cows. The diet was formulated keeping in mind the nutritional requirements of postpartum dairy cows (NRC, 2001) and included the constituents listed: $71.87 \%$ corn silage, $10.27 \%$ predried oats, $12.32 \%$ citrus pulp, $4.52 \%$ soybean meal, $0.82 \%$ vitamin complex, and $0.21 \%$ urea. o Water ad libitum was allowed to cows.

The cows were monitored from 30 days before parturition until 63 days postpartum. The 27 animals were categorized into two groups based 
on their LS scores, where LS 1 indicated animals without lameness, LS 2 indicated those suspected of lameness and LS 3, 4 and 5 represented those with mild, moderate and severe lameness, respectively (SPRECHER, 1997), and this assessment was made at the beginning of the experimental period. The group of lame cows (LC) $(\mathrm{n}=15)$ included those animals with LS equal to or more than 3 , while the group of non-lame cows (NLC) $(\mathrm{n}=12)$ had an LS value of 1 . The LS evaluation was performed monthly throughout the experimental period, and only the animals that maintained the same LS throughout the experiment were retained in the study.

Milk production was measured twice a day from 7 days postpartum (DPP) to 63 days postpartum using the GEA digital milking system reader. The BCS was assessed 30 days prior to parturition and on days 30 and 63 postpartum, via visual evaluation accomplished by the same technician, utilizing a fivepoint scale, where 1 is a cachectic animal and the degree of obesity is equal to a score of 5 (WILDMAN et al., 1982). Blood collection were realized on day 0 at parturition, and days 7,14 , and 21 days postpartum. Blood was collected from the coccygeal arteriovenous complex using a vacutainer system, into tubes without anticoagulant for the posterior evaluation of the BHB, urea, phosphorus, calcium, aspartate aminotransferase, gamma glutamyl transferase and total plasmatic proteins concentrations. Immediately, post the blood collection, the samples were centrifuged at 1800 rpm for 15 minutes, processed, and frozen at -20 ${ }^{\circ} \mathrm{C}$ in microtubes, until the time of further analysis. The analyses of all the parameters were performed with the LabmaxPlenno apparatus using specific commercial kits (Labtest Diagnóstica S.A., Brazil). The BHB concentration was obtained using a commercial kit (Wako BHBA-HR, Wako Chemicals, USA).

Statistical analyses were done using SAS software (SAS 9.1- SAS Institute Inc., Cary, NC, USA). The variables were analyzed incorporating the MIXED procedure, taking into account the effect of the group, time (collection) and their interaction (group* collection), considering a significance level of $\mathrm{p}<0.05$ and tendency of $\mathrm{p}<0.1$. The Tukey test was used to compare the means.

\section{RESULTS}

The average milk yield was lower in lame cows $(17.675 \pm 0.31 \mathrm{~L} /$ day) when compared to the non-lame cows $(22.27 \pm 0.42 \mathrm{~L} /$ day; $\mathrm{p}<0.001)$ (Figure 1). Besides, from days 7 to 28, the production between the groups was similar; however, from days 35 to 63 it was lower in the lame cows, indicating that this period was critical for these animals.

The BCS (Figure 2), another visual evaluation, closely linked to the LS due to its inversely proportional relationship, provided results that

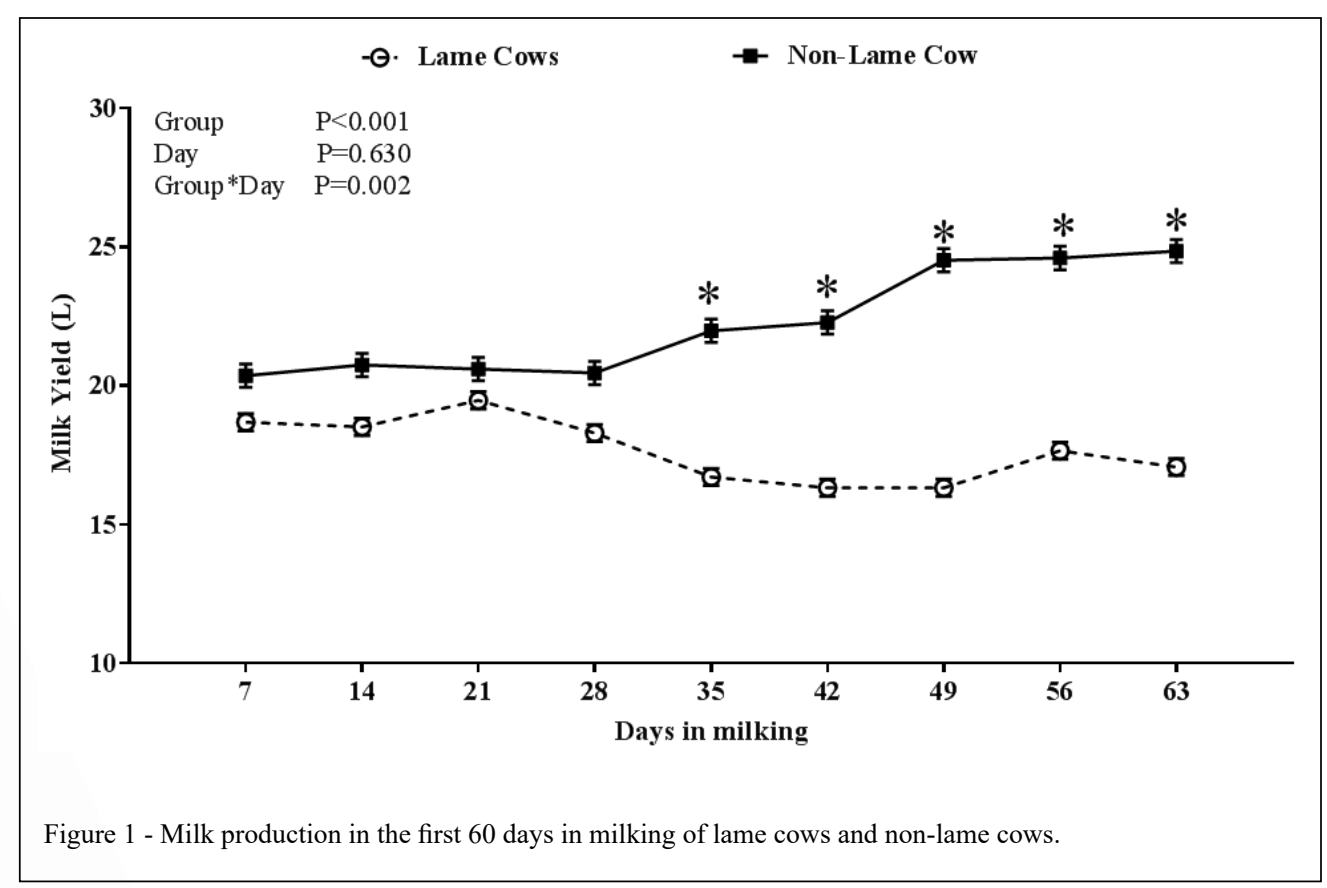

Ciência Rural, v.50, n.5, 2020. 


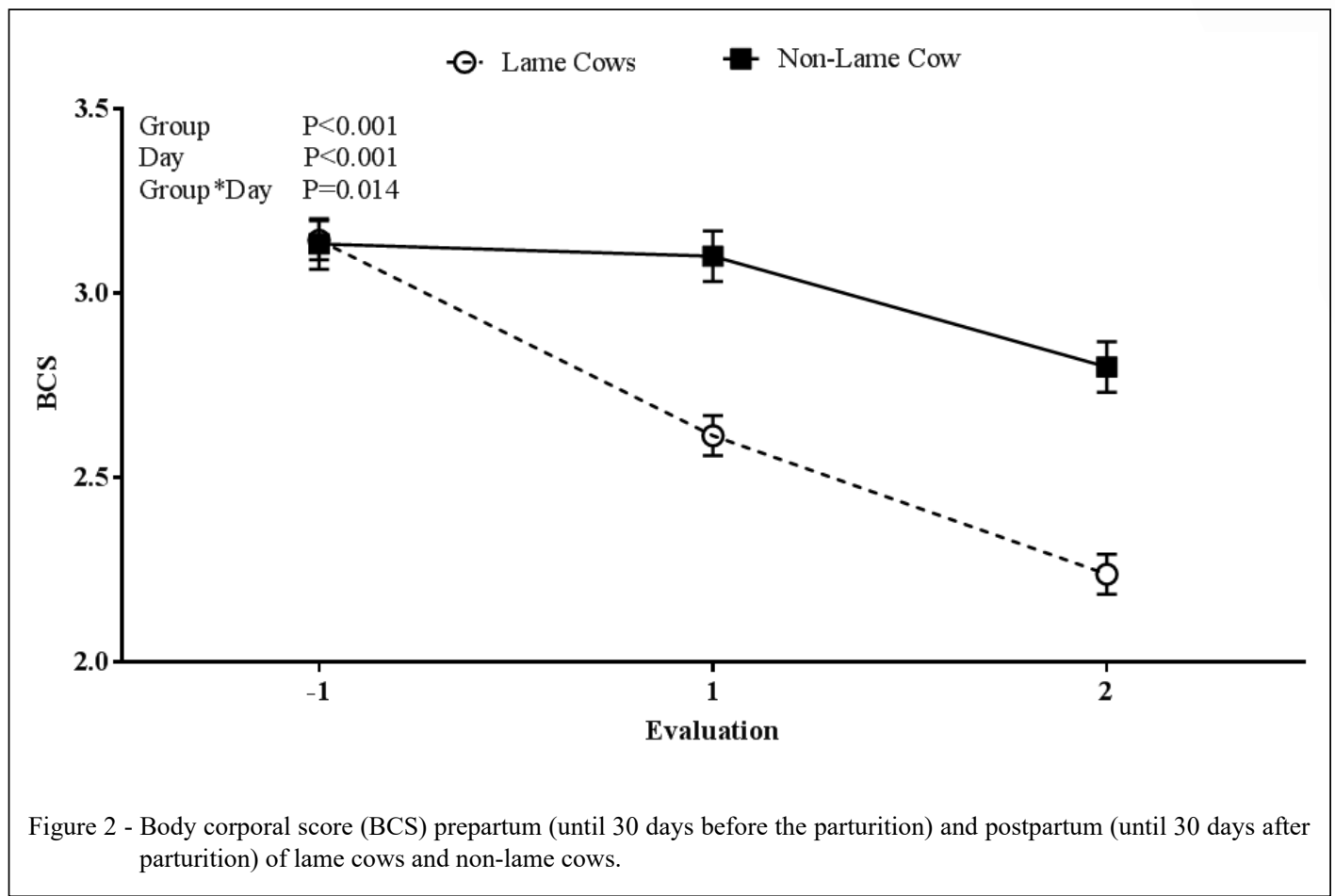

gained very little comment in the literature. Lame cows, even those with BCS equal to healthy cows at prepartum,suffered significantly more during the recent postpartum $(\mathrm{p}<0.001)$ as their BCS score was 2.5. \pm 0.15 , while that of the healthy group was $3.0 \pm 0.22$.

Serum calcium concentration was lower $(\mathrm{p}<0.001)$ in the cows with claudication (LC), in comparison with that of the healthy cows (NLC) during the period evaluated (Figure 3); it was clear that the NLC presented calcemia of $9.63 \pm$ 0.13 , while the LC showed values of $7.42 \pm 0.12$, suggestive of subclinical hypocalcemia.

The total plasma protein results tended to be higher $(\mathrm{p}=0.08)$ in the non-lame cows, with values of $7.986 \pm 0.112$, compared to those of the cows with claudication, $7.724 \pm 0.09$ (Table 1). Among the parameters evaluated, the metabolites AST, GGT, PPT, urea, BHB and phosphorus revealed no statistical difference between the groups during this period (Table 1).

\section{DISCUSSION}

Milk production during the first 63 days of lactation in the cows withlameness was approximately $22 \%$ less than that of the healthy cows. Cows with claudication produced $17.675 \pm 0.310$ liters per day, while the control group produced $22.271 \pm 0.425$, thus demonstrating the importance of the LS evaluation as a reliable tool even at the time of prepartum.

Considering that the cows with lameness revealed an abrupt drop in production, precisely at the time when they started or reached lactation peak (at 40 days after calving) it is important to highlight that changes at this time will probably lead to greater losses for the farmer. According to MARTINEZ (2010), when a cow loses $0.5 \mathrm{~kg}$ of milk without peak lactation, it is equivalent to a production loss of $110 \mathrm{~kg}$ of milk in the total lactation, thus demonstrating the extent to which prepartum lameness impacts these animals.

ROBINSON (2001) cited that cows with LS 2 revealed a $4 \%$ decrease in their real production capacity, with this relationship showing an increase in geometric progression. Therefore, a cow with LS 5 loses $32 \%$ of its real productive capacity. However, reports are available of significantly even greater reduction in cows with evident claudication, reaching up to more than $50 \%$ of the total production (WARNICK et al., 2001). In fact, GREEN et al., (2014) demonstrated that cows with lameness commenced the process of decrease in milk production, even prior to being diagnosed with the lameness, which clearly emphasizes the importance 


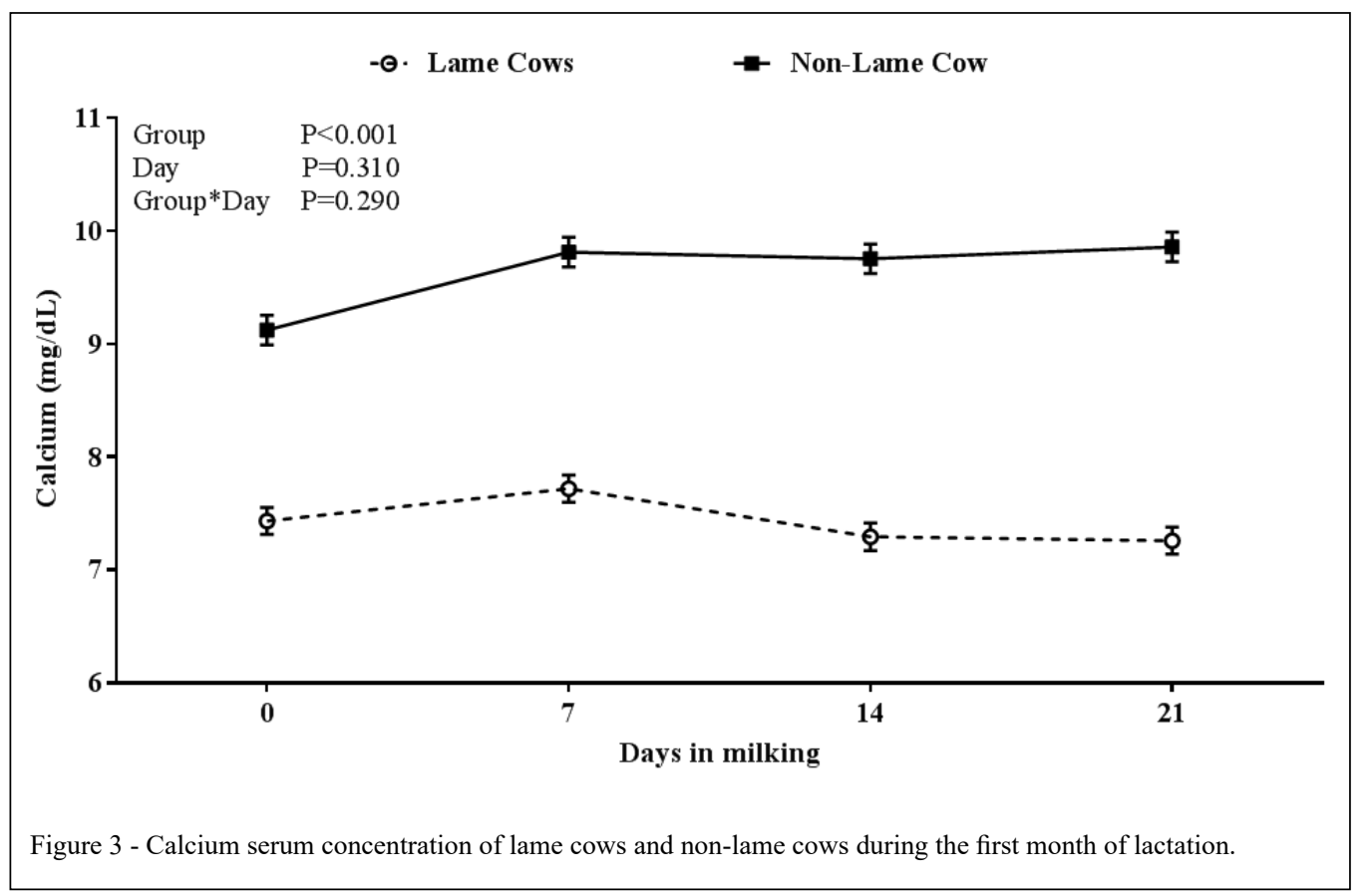

of early identification of subclinical lameness; and thus, reducing the damage induced.

Subjective observational methods, such as LS and EBCS, have been extensively employed for the assessment of different degrees of lameness and nutritional status in the cattle population. However, during the prepartum period, no studies have been done on the relationship between BCS $\mathrm{x}$ LS and milk production (BARBOSA et al., 2016). In the present study it is evident that; although, the animals presented the same BCS at 30 days prior to calving, the cows with lameness showed greater BCS losses during the first months of lactation. This demonstrated that animals with problems related to foot lameness experience the metabolic challenges imposed by the beginning of lactation more intensely, ultimately culminating in a sharp drop in the BCS. Thus, the presence of an inverse relationship between BCS and LS is very clear, as the BCS has a positive correlation with the digital cushion thickness which, in turn, plays a significant role in minimizing digital concussion with the ground. It can be speculated that the occurrence of prepartum lameness induces a higher postpartum BCS loss. This may have resulted in a reduction in the cushioning offered by the digital cushion, thus giving these animals even greater susceptibility to the negative effects of lameness (BARBOSA et al., 2016).

Many variables may contribute to changes in the digital cushion, including adipose tissue

Table 1 - Metabolites evaluated (average \pm standard error) in lame and non-lame Holstein cows during the prepartum.=

\begin{tabular}{lccccc}
\hline & Lame Cows & Non-lame Cows & & \multicolumn{2}{c}{ P Value } \\
\hline Metabolites & Group & group & Group & Day & G $^{*} \mathrm{D}$ \\
BHB (U/L) & $0.751 \pm 0.050$ & $0.654 \pm 0.050$ & 0.172 & $<0.001$ & 0.060 \\
Urea (mg/dL) & $30.876 \pm 1.087$ & $30.481 \pm 1.575$ & 0.838 & 0.923 & 0.755 \\
AST (U/L) & $77.611 \pm 3.017$ & $71.425 \pm 2.584$ & 0.125 & $<0.001$ \\
GGT (U/L) & $29.723 \pm 2.038$ & $30.686 \pm 2.058$ & 0.741 & 0.126 & 0.497 \\
Phosphorus (mg/dL) & $6.200 \pm 0.160$ & $6.000 \pm 0.311$ & 0.15 & $<0.15$ \\
PPT (mg/dL) & $7.724 \pm 0.098$ & $7.986 \pm 0.112$ & 0.085 & $<0.001$ & 0.560 \\
\hline
\end{tabular}

Ciência Rural, v.50, n.5, 2020. 
thickness, and these factors could probably affect the hoof-suspending apparatus such as parturition, laminar pathology or even prior poorly-understood, lameness-related physiological mechanisms that could incorporate insulin resistance and loss in body condition (BICALHO et al., 2009; CECEN et al., 2015; NEWSOME et al., 2017), besides the extrinsic risk factors, like environment and humidity. Further, recent research has identified that nonpregnant dairy cows fed on a high-energy diet prior to slaughter possessed greater up-regulation of the lipogenic genes within the digital cushion (IQBAl et al., 2016), Because the negative energy balance or physiological state with lipolytic pathways and fat mobilization of the padded digital cushion are not as yet clearly understood, it appears that lameness and its relationship with BCS and digital cushion remain an area which requires greater study and exploration.

From the blood mineral analysis, calcium and calcemia were in lower concentrations from the time of parturition in the cows with claudication, and remained thus throughout the experimental period.

This fact was explained by BARBOSA et al., (2016) where the epidermal cell differentiation showed high sensitivity to changes in the levels of plasma calcium. This study showed that in the cows with hypocalcemia, the corneal layer tissues were deficient in keratinization, from which the part played by calcium on epidermal cell differentiation was deduced.

According to BARBOSA et al., (2016) there is a strong relationship between calcium concentration on horny tissue and keratinocyte production, promoting the activation of epidermal transglutaminase, which participates in the binding process between the keratin fibers of the cell envelope and the final epidermal cell differentiation. There is some speculation that normocalcemia and mild calcium ion deficiency in the horny tissue, when related to lower local magnesium concentration, may be linked to circulatory failure in the digital tissue of cows with lameness. Considering how minerals such as magnesium act as an enzymatic cofactor, these findings may contribute to a better understanding of the occurrence of lasting or permanent damage to the foot horn.

Already the PPT values revealed an approximation of significance between the groups during the period, with healthy cows revealing higher values. It should be noted that cows with difficulty in walking significantly reduced the dry matter intake by up to $36 \%$ compared with healthy cows (ROBINSON, 2001); therefore, knowing that the PPT is the sum total of the globulins and serum albums, it is acknowledged that albuminemia can be affected by the protein intake by the cows with claudication having the lower dry matter intake, up to $10 \%$ less compared to the normal cows (ROBINSON, 2001); therefore, with lesser food consumption lower levels of albumin in the cows with claudication may have probably caused this result. similar reports have also been recorded by ALGERS et al., (2009). They described that cows with locomotive infections have lower immune response capacity because they possess smaller immune cells and lower quality of that same immune response reflected directly in a smaller quantity of globulins which; therefore, are the same factors subject to exclusive use by those and lower PPT levels in recent times.

The AST, GGT, urea, BHBA and phosphorus values have been included within the reference values throughout the experimental period (GONZALES, 2003). Therefore, these differences were not considered significant in terms of the effects of lameness because metabolic homeostasis, to date, was being maintained.

\section{CONCLUSION}

The lameness evident in cows prior to parturition exerted major negative reflexes on the milk yield and calcemia in these animals, making the LS evaluation at prepartum a significant tool for the early diagnosis of future lactation damage. However, the impact of prepartum lameness on subsequent lactation continues to be less explored, largely because most producers neglect the dry period. Meanwhile, the reality is that this period requires just as much attention as lactation does, as this is the period when the greatest control and prophylaxis measures should be taken to ensure that the next lactation is as healthy and profitable, as possible.

\section{ACKNOWLEDGMENTS}

The authors extend their gratitude to the Núcleo de Pesquisa, Ensino e Extensão em Pecuária (NUPEEC) for providing the database used in this study. Moreover, the authors extend their acknowledgments for financed in part by the Coordenação de Aperfeiçoamento de Pessoal de Nível Superior (CAPES), Brasil - Finance code 001."

\section{BIOETHICS AND BIOSSECURITY COMMITTEE APPROVAL}

All the procedures involving animals in this study were approved by the University of Pelotas Animal Care and Use, Committee number23110.009378/2016-01. 


\section{DECLARATION OF CONFLICT OF INTERESTS}

The authors declare no conflict of interest. The founding sponsors had no role in the design of the study; in the collection, analyses, or interpretation of data; in the writing of the manuscript; and in the decision to publish the results.

\section{AUTHORS' CONTRIBUTIONS}

All authors contributed equally for the conception and writing of the manuscript. All authors critically revised the manuscript and approved of the final version.

\section{REFERENCES}

ALGERS B. et al. Scientific opinion on the overall effects of farming systems on dair cow. The EFSA Journal, v.1143, p.1-38, 2009. Available from: <https://www.efsa.europa.eu/en/ efsajournal/pub/1143>. Accessed: Jan.18, 2019. doi: 10.2903/j. efsa.2009.1143.

BARBOSA A. A. et al. Concentration of minerals in the hoof horny capsule of healthy and lame dairy cows. Semina: Ciências Agrárias, v.37, n.3, p.1423-1430, 2016. Available from: <http://www.uel.br/revistas/uel/index.php/ semagrarias/article/view/20436>. Accessed: Jan. 15, 2019. doi: $10.5433 / 1679-0359.2016 \mathrm{v} 37 \mathrm{n} 3 \mathrm{p} 1423$.

BARBOSA A. A. et al. Relationship between body condition score and locomotion score on dairy cows submitted to semiextensive feeding management. Arquivo Brasileiro de Medicina Veterinária e Zootecnia, v.70, n.4, p.1129-1134, 2018 Available from: <http://www.sc09352018000401129\&script=sci abstract\&tlng=pt $>$. Accessed: $\quad$ Feb. $\quad 15,2019 . \quad$ doi: $10.1590 / 1678-4162-9978$

BICALHO R. C. et al. Lameness in dairy cattle: a debilitating disease or a disease of debilitated cattle? A crosssectional study of the prevalence of lameness and the thickness of the digital cushion. Journal of Dairy Science, v.92, n.7, p.3175-3184, 2009. Available from: <https://www.journalofdairyscience.org/article/ S0022-0302(09)70634-4/fulltext>. Accessed: Feb. 15, 2019. doi $10.3168 /$ jds.2008-1827.

BOGETOFT P. Performance benchmarking: measuring andmanaging performance. 1. ed. New York: Springer,2012.

CECEN G. H. et al. Ultrasonographic and macroscopic comparison of the thickness of the capsule, corium, and soft tissues in bovine claws: An in vitro study. Journal of Veterinary Science, v.16, n.1, p.107-112, 2015. Available from: $<$ https://www.ncbi.nlm.nih.gov/ pmc/articles/PMC4367139/pdf/jvs-16-107.pdf>. Accessed: Jan. 10, 2019. doi: 10.4142/jvs.2015.16.1.107.

CHA E. et al. The cost of different types of lameness in dairy cows calculated by dynamic programming: Preventive Veterinary Medicine, v.97 n.1, p.1-8, 2010. Available from: < https://www. ncbi.nlm.nih.gov/pubmed/20801533>. Accessed: Jan. 10, 2019. doi: 10.1016/j.prevetmed.2010.07.011.

CHAPINAL, N. et al. Lameness and hock injuries improve on farms participating in an assessment program. Veterinary Journal, v.202, n.3, p.646-648, 2014.
COSTA, J. H. C. et al. Prevalence of lameness and leg lesions of lactating dairy cows housed in southern Brazil: Effects of housing systems. Journal of Dairy Science, v.101, n.3, p.23952405, 2018. Available from: <https://www.ncbi.nlm.nih.gov/ pubmed/29274968>. Accessed: Jan. 08, 2019. doi: 10.3168/ jds.2017-13462.

DRACKLEY J. K. Biology of dairy cows during the transition period: the final frontier? Journal of Dairy Science, v.82, n.11, p.22592273, 1999. Available from: <https://www.journalofdairyscience. org/article/S0022-0302(99)75474-3>. Accessed: Jan. 10, 2019. doi: 10.3168/jds.S0022-0302(99)75474-3.

GREEN L. E. et al. Temporal associations between low body condition, lameness and milk yield in a UK dairy herd. Preventive Veterinary Medicine, v.113, n.1, p.63-71, 2014. Available from: $<$ https://www.ncbi.nlm.nih.gov/pubmed/24183787>. Accessed: Feb. 15, 2019. doi: 10.1016/j.prevetmed.2013.10.009.

GREENOUGH, P. R. Bovine laminitis and lameness: a hands-on approach. Saskatoon:Saunders Ltd., 2007. 311p.

IQBAL Z. M. et al. Digital cushion fatty acid composition and lipid metabolism gene network expression in Holstein dairy cows fed a highenergy diet. PLoS One, v.11, n.7, p.e0159536, 2016. Available from: $<$ https://www.ncbi.nlm.nih.gov/pubmed/27441691>. Accessed: Feb. 15, 2019. doi: 10.1371/journal.pone.0159536.

LEACHK.A. etal. Reducing lameness in dairy herds-Overcoming some barriers. Research in Veterinary Science, v.94, n.3, p.820-825, 2013. Available from: <https:/www.ncbi.nlm.nih.gov/pubmed/23158851>. Accessed: Feb. 15, 2019. doi: 10.1016/j.rvsc.2012.10.00.

MARTINEZ J. C. 2010. Guia rápido para nutrição de vacas leiteiras, Milkpoint. Available from: <http://www.portaleducacao.com.br/ veterinaria/artigos/18023/curva-de-lactacaoem-vacas-leiteiras $>$. Accessed: Feb. 15, 2019.

MORIARTY J. P. A theory of benchmarking. Benchmarking. An International Journal, v.18, n.4, p.588-611, 2011. Available from: $<$ https://www.researchgate.net/publication/27815144_A theory_of_benchmarking $>$. Accessed: Feb. 15, 2019. doi: $10.1108 / 14635771111147650$.

NRC (NATIONAL RESEARCH COUNCIL). Nutrient requirements of Dairy Cattle. Washington: Academy Press, 2001. 381p.

NEWSOME R. F. et al. A prospective cohort study of digital cushion and corium thickness. Part 1: Associations with body condition, lesion incidence, and proximity to calving. Journal of Dairy Science, v.100, n.6, p.4745-4758, 2017. Available from: <https:// www.sciencedirect.com/science/article/pii/S0022030217303430>. Accessed: Feb. 15, 2019. doi: 10.3168/jds.2016-12012.

ROBINSON P. H. 2001. Locomotion Scoring Dairy Cows. Cooperative Extension Specialist, University of California. Available from: <https://animalscience.ucdavis.edu/sites/g/ files/dgvnsk446/files/inlinefiles/web201312_locomotion_scoring your_cows.pdf>.Accessed: Feb. 15, 2019.

ŠÁROVÁ, R. et al. Farm managers underestimate lameness prevalence in Czech dairy herds. Animal Welfare, v.20, n.2, p.201-204, 2011. Available from: <https://www.researchgate.net/ publication/236944492_Farm_managers_underestimate_lameness prevalence_in_Czech_dairy_herds $>$. Accessed: Feb. 15, 2019. 
SOUZA R. C. et al. Perdas econômicas ocasionadas pelas enfermidades podais em vacas leiteiras confinadas em sistema free stall. Arquivo Brasileiro de Medicina Veterinária e Zootecnia, v.58,n.6, p.982-987, 2006. Available from: <http://www.scielo. br/scielo.php?pid $=$ S0 $10209352006000600002 \&$ script $=$ sci abstract\&tlng=t $>$. Accessed: Feb. 15, 2019. doi: 10.1590/S010209352006000600002 .

SPRECHER D. J. et. al. Lameness scoring system that uses posture and gait to predict dairy cattle reproductive performance. Theriogenology, v.47, p.1178-1187. 1997. Available from: <https://www.sciencedirect.com/science/ article/pii/S0093691X97000988?via\%3Dihub $>$. Accessed: Mar. 05, 2019. doi: 10.1016/s0093-691x(97)00098-8.

TOMASELlA T. E. et al. Prevalência e classificação de lesões podais em bovinos leiteiros na região de Belo Horizonte - MG.
Revista Brasileira de Higiene e Sanidade Animal, v.8, n.1, p.115-128, 2014. Available from: <https://pdfs.semanticscholar. org/7ebe/cf0aeae5359b6cc8cbb75e87974eb2b2f70b.pdf >. Accessed: Feb. 15, 2019. doi: 10.5935/1981-2965.20140008.

WARNICK L. D. et al. The effect of lameness on milk production in dairy cows. Journal of DairyScience, v.84, n.9, p.19881997, 2001. Available from: <https:/www.ncbi.nlm.nih.gov/ pubmed/11573778>. Accessed: Feb. 15, 2019. doi: 10.3168/jds. S0022-0302(01)74642-5.

WILDMAN E. E. et al. A dairy body condition scoring system and its relationship toselected production characteristics. Journal of Dairy Science, v.65, n.3, p.495-501, 1982. Available from: <https://www.journalofdairyscience.org/article/S0022 0302\%2882\%2982223-6/abstrac>. Accessed: Jan. 10, 2019. doi: $10.3168 /$ jds.S0022-0302(82)82223-6. 